NOTE

\title{
Effect of repeated tissue sampling on growth rates of juvenile loggerhead turtles Caretta caretta
}

\author{
Karen A. Bjorndal*, Kimberly J. Reich, Alan B. Bolten \\ Archie Carr Center for Sea Turtle Research and Department of Biology, University of Florida, PO Box 118525, Gainesville, \\ Florida 32611, USA
}

\begin{abstract}
We evaluated the effect of repeated tissue sampling on growth rates of juvenile loggerhead sea turtles Caretta caretta. Samples of blood, skin, and scute (keratinized epidermal layer covering the bony shell) were collected at 3 intervals over a $120 \mathrm{~d}$ period from 37 loggerheads; 8 control turtles were not sampled. No infections or scarring occurred at the sampling sites, and growth in mass of experimental and control turtles was not significantly different. The sampling regime did not affect the health or physiological status of the turtles.
\end{abstract}

KEY WORDS: Well-being $\cdot$ Repeated sampling $\cdot$ Growth $\cdot$ Marine turtles

Resale or republication not permitted without written consent of the publisher

\section{INTRODUCTION}

An important concern of biologists is the effect of research on the health and physiological status of their study animals (Mendez et al. 2008, Caputo et al. 2009). Several studies have assessed the effects of research manipulations on reproduction and behavior of sea turtles (Bjorndal 1982, Broderick \& Godley 1999, Fossette et al. 2008, Sherrill-Mix \& James 2008). During a study (Reich et al. 2008) of the contributions of growth and catabolic turnover to the rate of ${ }^{13} \mathrm{C}$ and ${ }^{15} \mathrm{~N}$ incorporation into several tissues of loggerhead turtles Caretta caretta, we collected samples of 3 tissues (blood, skin, and scute). In this paper, we evaluate the effect of our tissue sampling regime on the growth rates of loggerheads by comparing growth in mass of turtles from which tissue samples were collected with growth of control turtles. Rate of mass growth of an organism is an excellent indicator of physiological status because growth in mass represents an integration of nutritional status, health, and physiological condition (Ricklefs \& Miller 1999, Karasov \& Martínez del Rio 2007).

\section{MATERIALS AND METHODS}

Loggerhead hatchlings were collected in June 2002 from hatcheries in Broward County, Florida, and were maintained in saltwater aquaria in the Department of
Zoology, University of Florida (Gainesville, FL, USA). We glued a small plastic identification disc $(2 \mathrm{~mm}$ diameter) to the carapace (upper shell) of each turtle. Turtles were housed in indoor tanks at $26.5^{\circ} \mathrm{C}\left( \pm 1^{\circ}\right)$ on a 12:12 h light:dark cycle with $20 \mathrm{~W}$ full spectrum fluorescent bulbs (vita-light) and $60 \mathrm{~W}$ outdoor flood lights. Turtles were fed daily ( $3 \%$ of body mass); food remaining after 45 min was removed from the tank. The pelleted diet (Mellick Aquafeed) contained 30\% crude protein and $3 \%$ lipids; soy protein isolate was the main protein source.

The trial was started on 1 July and continued for $120 \mathrm{~d}$. Every $10 \mathrm{~d}$ for the duration of the study, each turtle was patted dry with paper towels and weighed to $0.1 \mathrm{~g}$. The tissues collected for the stable isotope study (Reich et al. 2008) were blood, skin, and scute (the keratinized epidermal layer that covers the shells of turtles). These tissues were selected because they can be sampled with minimally invasive techniques, and we wanted to release the turtles unharmed at the end of the study. Turtles were divided among 4 sampling groups, and each turtle was sampled 3 times for each of the 3 tissues over the $120 \mathrm{~d}$ trial (Table 1). To decrease stress on the animal, blood was collected on $1 \mathrm{~d}$, and skin and scute were collected 3 to $6 \mathrm{~d}$ later. The interval between the first 2 sample collections ranged from 30 to $34 \mathrm{~d}_{\text {; }}$ the interval between the second and third sample collections ranged from 53 to $55 \mathrm{~d}$. A control group of 8 turtles was maintained throughout the trial under identical environ- 
Table 1. Caretta caretta. Sample collection schedule for loggerhead hatchlings. The turtles were first weighed on 1 July (Day 0) and last weighed on 29 October (Day 120)

\begin{tabular}{|cccc|}
\hline & Blood & Skin & Scute \\
\hline Group A & $1 \mathrm{Jul}$ & $5 \mathrm{Jul}$ & $5 \mathrm{Jul}$ \\
& $2 \mathrm{Aug}$ & $8 \mathrm{Aug}$ & $8 \mathrm{Aug}$ \\
& $26 \mathrm{Sep}$ & $30 \mathrm{Sep}$ & $30 \mathrm{Sep}$ \\
Group B & $7 \mathrm{Jul}$ & $11 \mathrm{Jul}$ & $11 \mathrm{Jul}$ \\
& $8 \mathrm{Aug}$ & $13 \mathrm{Aug}$ & $13 \mathrm{Aug}$ \\
& $1 \mathrm{Oct}$ & $5 \mathrm{Oct}$ & $5 \mathrm{Oct}$ \\
Group C & $14 \mathrm{Jul}$ & $18 \mathrm{Jul}$ & $18 \mathrm{Jul}$ \\
& $13 \mathrm{Aug}$ & $17 \mathrm{Aug}$ & $17 \mathrm{Aug}$ \\
& $7 \mathrm{Oct}$ & $10 \mathrm{Oct}$ & $10 \mathrm{Oct}$ \\
Group D & $22 \mathrm{Jul}$ & $26 \mathrm{Jul}$ & $26 \mathrm{Jul}$ \\
& $21 \mathrm{Aug}$ & $26 \mathrm{Aug}$ & $26 \mathrm{Aug}$ \\
& $15 \mathrm{Oct}$ & $19 \mathrm{Oct}$ & $19 \mathrm{Oct}$ \\
\hline
\end{tabular}

mental conditions. The 8 control turtles were weighed every $10 \mathrm{~d}$, but no tissue samples were collected. After the study, all turtles were released into the Atlantic Ocean under Florida Fish and Wildlife Conservation Commission guidelines.

Before tissues were collected, the sampling sites were cleaned with isopropyl alcohol. No anesthetizing agent was used. Approximately $0.2 \mathrm{ml}$ of blood was collected, with a 25-gauge needle and syringe, from the dorsal cervical sinus (Owens \& Ruiz 1980). Skin samples were collected from the dorsal surface of the 'shoulder' region using a $2 \mathrm{~mm}$ sterile biopsy punch. Scute samples were collected from the newly grown, anterior edge of the second lateral scute by scoring $\sim 6 \mathrm{~mm}^{2}$ with a \# 21 scalpel blade and peeling the scute from the carapace with forceps.

To test for the effect of tissue sampling on growth, body mass at initiation and end of the $120 \mathrm{~d}$ trial was compared for the control $(\mathrm{n}=8)$ and experimental $(\mathrm{n}=$ 37) turtles with $t$-tests. All statistical tests were conducted in S-Plus (v. 7.03) with alpha $=0.05$.

\section{RESULTS AND DISCUSSION}

Collection of tissue samples had no effect on growth rates of experimental turtles compared with those of the controls. At the beginning of the trial $\left(\mathrm{T}_{0}\right)$, hatchlings $(\mathrm{n}=45$ ) ranged from 15.3 to $21.6 \mathrm{~g}$ in body mass $($ mean $\pm \mathrm{SD}=19.3 \pm 1.4)$. There was no difference between initial body mass in the experimental $(n=37)$ and control $(\mathrm{n}=8)$ hatchlings $(t$-test, $\mathrm{t}=-1.412$, $\mathrm{df}=43$, $\mathrm{p}=0.196)$. At the end of the trial, body masses of the 2 groups were not significantly different ( $t$-test, $t=$ 0.566, df $=43, \mathrm{p}=0.574$ ). Visual inspection of the growth trajectories in Fig. 1 reveals complete overlap between control and experimental turtles, again demonstrating no effect of repeated sampling on mass

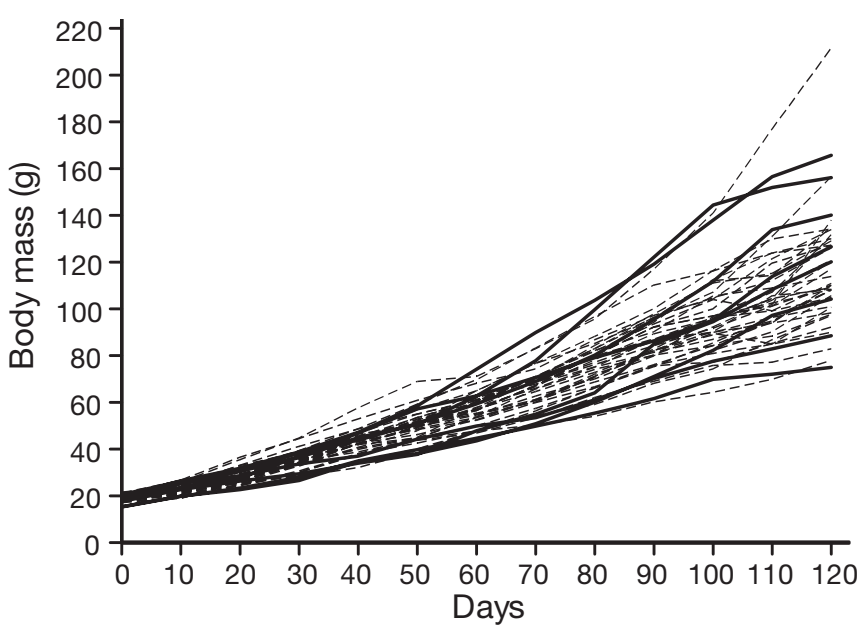

Fig. 1. Caretta caretta. Trajectories for growth in mass of juvenile loggerhead turtles during a $120 \mathrm{~d}$ trial. Turtles from which tissue samples were collected $(\mathrm{n}=37$, dashed lines) grew at the same rate ( $\mathrm{p}>0.05$, see 'Results and discussion') as control turtles ( $\mathrm{n}=8$, solid lines).

gain. During the $120 \mathrm{~d}$ experimental period, growth trajectories were highly variable among individuals. This level of variation in growth rates among individual turtles is typical for sea turtles in captivity (Swingle et al. 1993, Roark et al. 2009) and in the wild (Bjorndal et al. 2000, Braun-McNeill et al. 2008).

From our study, it is clear that the type and extent of tissue sampling in our study did not have a negative effect on mass gain in the turtles. All areas where tissues were sampled healed rapidly with no indication of infections or scarring. We conclude that this sampling regime did not have a negative effect on the health and physiological status of the turtles.

Additional studies that evaluate the effect of a range of research procedures on the health and physiological status are needed in many species. When possible, studies should be designed to test for effects of research manipulation on the study animals, and results of these studies should be made available.

Acknowledgements. We thank F. Davis, P. Eliazar, T. Garcia, H. Jacobson, S. Luciano, N. Osman, J. Pfaller, and J. Sankar for their assistance with turtle care and sample collection. This project was funded by Disney Wildlife Conservation Fund, National Marine Fisheries Service, US Fish and Wildlife Service, and Florida Fish and Wildlife Conservation Commission (FWC) Marine Turtle Grants Program. The study was conducted under permits issued by FWC (TP\# 016) and the University of Florida Institutional Animal Care and Use Committee (permit Z094).

\section{LITERATURE CITED}

Bjorndal KA (1982) Does turning green turtles on their backs affect subsequent reproductive performance? Mar Turtle Newsl 22:15-16 
Bjorndal KA, Bolten AB, Chaloupka MY (2000) Green turtle somatic growth model: evidence for density dependence. Ecol Appl 10:269-282

Braun-McNeill J, Epperly SP, Avens L, Snover ML, Taylor JC (2008) Growth rates of loggerhead sea turtles (Caretta caretta) from the western North Atlantic. Herpetol Conserv Biol 3:273-281

Broderick AC, Godley BJ (1999) Effect of tagging marine turtles on nesting behaviour and reproductive success. Anim Behav 58:587-591

Caputo M, O'Connor CM, Hasler CT, Hanson KC, Cooke SJ (2009) Long-term effects of surgically implanted telemetry tags on the nutritional physiology and condition of wild freshwater fish. Dis Aquat Org 84:35-41

Fossette S, Corbel H, Gaspar P, Le Maho Y, Georges JY (2008) An alternative technique for the long-term satellite tracking of leatherback turtles. Endang Species Res 4:33-41

Karasov WH, Martínez del Rio C (2007) Physiological ecology: how animals process energy, nutrients, and toxins. Princeton University Press, Princeton, NJ

Mendez D, Webb R, Berger L, Speare R (2008) Survival of the

Editorial responsibility: Alex Hyatt,

Geelong, Victoria, Australia amphibian chytrid fungus Batrachochytrium dendrobatidis on bare hands and gloves: hygiene implications for amphibian handling. Dis Aquat Org 82:97-104

Owens DW, Ruiz GJ (1980) New methods of obtaining blood and cerebrospinal fluid from marine turtles. Herpetologica 36:17-20

Reich KJ, Bjorndal KA, Martínez del Rio C (2008) Effects of growth and tissue type on the kinetics of ${ }^{13} \mathrm{C}$ and ${ }^{15} \mathrm{~N}$ incorporation in a rapidly growing ectotherm. Oecologia 155:651-663

Ricklefs RE, Miller G (1999) Ecology, 4th edn. WH Freeman, New York

Roark AM, Bjorndal KA, Bolten AB (2009) Compensatory responses to food restriction in juvenile green turtles (Chelonia mydas). Ecology 90:2524-2534

Sherrill-Mix SA, James MC (2008) Evaluating potential tagging effects on leatherback sea turtles. Endang Species Res 4:187-193

Swingle WM, Warmolts DI, Keinath JA, Musick JA (1993) Exceptional growth rates of captive loggerhead sea turtles, Caretta caretta. Zoo Biol 12:491-497

Submitted: June 15, 2009; Accepted: November 3, 2009 Proofs received from author(s): February 2, 2010 